\title{
Proximate Composition, Amino and Fatty Acid Profiles and Element Compositions of Four Different Moringa Species
}

\author{
T. Stadtlander ${ }^{1} \&$ K. Becker ${ }^{2}$ \\ ${ }^{1}$ Department of Livestock Sciences, Research Institute of Organic Agriculture, Frick, Switzerland \\ ${ }^{2}$ Institute for Animal Production in the Tropics and Subtropics, University of Hohenheim, Stuttgart, Germany \\ Correspondence: T. Stadtlander, Department of Livestock Sciences, Research Institute of Organic Agriculture, \\ Frick 5070, Switzerland. Tel: 0041-62-865-0439. E-mail: timo.stadtlander@fibl.org
}

Received: March 15, $2017 \quad$ Accepted: May 20, $2017 \quad$ Online Published: June 15, 2017

doi:10.5539/jas.v9n7p46 URL: https://doi.org/10.5539/jas.v9n7p46

\begin{abstract}
Several species of trees belong to the genus Moringa, but only one, Moringa oleifera (Lam.), has been intensively studied. No data has been published so far on the nutritional properties of M. stenopetala, M. drouhardii or M. hildebrandtii. In this study, kernels and leaves of M. oleifera, M. stenopetala, M. drouhardii and $M$. hildebrandtii have been analysed for their protein, fat, amino acid, fatty acid and macro- and microelements and discussed in relation to the known nutritional requirements of a young child. This study suggests that Moringa leaves, especially those of $M$. oleifera, are a suitable source of amino acids, vitamins and several elements but not for lipids and fatty acids. Moringa kernels are less suited as vegetable but are a suitable source for oils with $M$. oleifera seeds showing the best kernel to shell ratio.
\end{abstract}

Keywords: Moringa spp., leaf, kernel, nutrient composition

\section{Introduction}

The family Moringaceae is monogeneric, with medium sized trees belonging to 13 species of the genus Moringa (Leone et al., 2015). Most of those species are indigenous to Africa (11 species: Moringa arborea (Verdc.), M. rivae (Chiov.), M. borziana (Mattei), M. pygmaea (Verdc.), M. longituba (Engl.), M. stenopetala, M. ruspoliana (Engl.), M. ovalifolia (Dinter \& A. Berger), M. drouhardii, M. hildebrandtii and M. peregrina (Fiori)) while the remaining two species are indigenous to Asia (M. concanensis (Nimmo ex Dalzell \& Gibson) and $M$. oleifera) (Leone et al., 2015). The most widely known and studied species is M. oleifera, which has more records of various kinds of research (e.g. animal and human nutrition, phytotherapeutic treatment of various diseases, water purification, antioxidants, antidiabetic, bioactive secondary plant compounds) in scientific databases than of all the other 12 species combined.

Certainly one of the most important and investigated properties of $M$. oleifera is the ability of the seed powder to coagulate and flocculate suspended solids, including bacteria or other potential pathogens. The bioactive compound has been found to be a protein $(5 \mathrm{kDa})$ which reduces suspended solids and bacteria in water by $1.1-$ $4 \log$ units (Gassenschmidt, Jany, Tauscher, \& Niebergall, 1995; Ghebremichael, Gunaratna, Henriksson, Brumer, \& Dalhammar, 2005).

Due to this highly interesting and beneficial property, which was described in the 1980s by the German developmental aid service GTZ (Jahn, 1986), the tree has been introduced and established in almost every tropical and subtropical country (Anwar, Latif, Ashraf, \& Gilani, 2007; Leone et al., 2015). Dissemination has been facilitated by Moringa oleifera growing in almost all types of soils, except stiff, heavy clays, although it does not tolerate stagnate water or frequent flooding.

Other properties, which are especially relevant for nutrition and medicine, were only recognized and studied later. It has been found that all parts of $M$. oleifera can be used, which has led to one of its nicknames - "the miracle tree". For medicinal purposes, all parts of the plant (roots, leaves, seeds, bark, gum and flower) have been used to treat a multitude of diseases and deficiencies (Anwar et al., 2007). For nutritional purposes, the leaves can be used as food for humans (Thurber \& Fahey, 2009) and as feed for animals, including fishes such as Nile tilapia (Oreochromis niloticus L.) (Afuang, Siddhuraju, \& Becker, 2003; Richter, Siddhuraju, \& Becker, 2003), common carp (Cyprinus carpio L.) (Yuangsoi \& Masumoto, 2012), African catfish (Clarias gariepinus Burchell) 
(Hlophe \& Moyo, 2014), and poultry (Abbas, 2013). The flowers, fruits and immature pods are also used as vegetables: primarily in India, Pakistan, The Philippines, Hawaii and large parts of Africa (Anwar et al., 2007). Moringa oleifera leaf meal powder is increasingly recognized as a lifesaving nutritious food supplement; especially in countries where large parts of the population are undernourished. However, well-documented, clinical studies are still lacking (Thurber \& Fahey, 2009; Scheinert, 2015). The frequently reported nutritional benefits of leaf powder include that it has a relatively high protein content, ranging between $250 \mathrm{~g} / \mathrm{kg}$ dry matter (DM) (Richter et al., 2003) and $321 \mathrm{~g} / \mathrm{kg}$ of DM (Hlophe \& Moyo, 2014); optimal amino acid make up; and high amounts of vitamins, such as vitamin $\mathrm{C}$ and $\alpha$-tocopherol. Pro-vitamin A, in the form of $\beta$-carotenes, can reach up to, and sometimes exceed, $1000 \mathrm{mg} / \mathrm{kg}$ DM in M. oleifera (Babu, 2000; Nambiar \& Seshadri, 2001; Leone et al., 2015). Furthermore, it is rich in minerals such as calcium, potassium and iron (Makkar \& Becker, 1996; Afuang et al., 2003). The seeds contain even more protein, which has been reported to be as high as $367 \mathrm{~g} / \mathrm{kg}$ DM in untreated kernels (Makkar \& Becker, 1997) and $600 \mathrm{~g} / \mathrm{kg}$ DM in defatted kernel meal (Makkar \& Becker, 1997; Ben Salem \& Makkar, 2009). The seeds of M. oleifera are rich in oil (417 g/kg DM) (Makkar \& Becker, 1997), which is widely known as Ben oil, and is edible, very rancidity resistant (Fahey, 2005) and usually similar to olive oil in its fatty acid profile (Ben Salem \& Makkar, 2009). In addition to the nutritional value of $M$. oleifera oil, a number of medicinal properties have been reported for M. oleifera seeds (Anwar et al., 2007). Moringa oleifera leaves and kernels may contain some secondary plant compounds such as total phenols, tannins, saponins and phytate in varying concentrations (Makkar \& Becker, 1996, 1997).

In contrast to the extensive body of published knowledge on the properties of $M$. oleifera, information on the other Moringa species, such as M. stenopetala, M. drouhardii and M. hildebrandtii is scarce. To begin to address this knowledge gap, we report nutritive values (proximate composition, amino and fatty acid profiles and mineral trace element and heavy metal compositions for seeds and leaves of $M$. stenopetala, M. drouhardii and $M$. hildebrandtii: each from one origin and compare them to values from leaves and seeds of M. oleifera from various locations. These values are in the end discussed in the context of the known nutritional requirements of a young child. The aim was to identify and report the suitability of the seeds or leaves from the different Moringa species and origins as nutritious and potentially locally grown food.

\section{Material and Methods}

\subsection{Plant Material}

Seed and leaf material from four different Moringa species were collected from Nicaragua, India, Ethiopia, Malawi, Israel, Madagascar, Thailand, Uganda and Gran Canary. M. hildebrandtii originally came from Madagascar and were grown in the Canary Islands. The harvesting time for the seeds was when the pots cut open, which ensures comparability. At each location, mixed samples representing 4-6 subsamples for leaves and seeds were taken.

\subsection{Seed Characteristics}

For each species, single seed mass (SSM), single kernel mass (SKM), seed hull mass (SHM) and ratio of kernel to seed mass (KSR) were determined by weighing 10 seeds and the respective kernels and hulls.

\subsection{Chemical Analysis}

The collected leaf and seed samples were immediately dried in a force drying oven at $45^{\circ} \mathrm{C}$. Small soft twigs were separated from the leaves before milling to $1 \mathrm{~mm}$ size. Seeds were de-shelled manually. Before analysis both leaves and kernels were dried to constant weight in a drying oven at $105^{\circ} \mathrm{C}$.

All analyses were carried out in duplicate. Dry matter (DM), crude protein (CP), crude lipids (CL) and amino acids (AA) were determined according to EC 152/2009 III sections A (DM), C (CP), H (CL), F (AA except Tryptophan) and G (Tryptophan). Fatty acids (FA) were determined using the trimethylsulfoniumhydroxid method (P23-5-008, the former DIN EN ISO 12966-3). The AA are presented as the percentage of crude protein and the FA are presented as the percentage of crude lipids. Fatty acid determination was not carried out for the leaves because their lipid content was generally very low (below 4\%). All reported chemical data refer to dry matter unless stated otherwise.

Macro elements (Ca, P, Mg, Na, K), micro elements (Fe, Mn, Mo, Se, Co, Cu, Zn, As, B, Si, V), harmful elements ( $\mathrm{Ag}, \mathrm{Al}, \mathrm{Ba}, \mathrm{Cd}, \mathrm{Ni}, \mathrm{Pb})$ and all other elements $(\mathrm{Cr}, \mathrm{Ge}, \mathrm{Li}, \mathrm{Sb}, \mathrm{Sn}, \mathrm{Sr})$ were determined by inductively coupled plasma optical emission spectrometry after microwave digestion (SAS-PA-01137). Dry matter, CP, CL, AA and FA were determined at the State Institute for Agricultural Chemistry of the University of Hohenheim, while the elemental analysis was conducted by SALUS Haus GmbH \& Co KG Analytischer Service (Bruckmühl, Germany). 
Leaf vitamins were determined in one sample of leaves from Malawi only. Determination was conducted by the commercial laboratory "ifp Institut für Produktqualität GmbH" (Berlin, Germany) according to the methods as stated in Table 8.

\subsection{Statistics}

The comparison between the seed and kernel morphometrics was conducted using SPSS Version 10.0. Levene's test was applied to test for homoscedasticity and the Kolmogorov-Smirnov test was applied to test for normal distribution of data. Due to lack of homoscedasticity and normal distribution, the nonparametric Kruskal-Wallis-H test was used to test for differences between the groups. In case where significant differences were found, the Mann-Whitney-U test was used to test the strength of the significance. The probability level for significance was set to $5 \%$.

\section{Results}

\subsection{Seed and Kernel Morphometrics}

Of the four different species tested, the seeds of $M$. oleifera were by far the lightest with an average SSM of 0.32 g., while the average SSM of M. stenopetala was $1.09 \mathrm{~g}$. The seeds of M. hildebrandtii, (average SSM = $3.82 \mathrm{~g}$ ) and $M$. drouhardii (average $\mathrm{SSM}=3.14 \mathrm{~g}$ ) were not statistically different from each other and were around ten times as heavy as the seeds of M. oleifera (Table 1). A similar result could be seen for the average SHM and SKM which was also lowest for $M$. oleifera and highest for $M$. hildebrandtii with no significant difference between $M$. drouhardii and M. hildebrandtii. The kernel to shell ratio, however, was highest for M. oleifera, where the kernel was more than three times the mass of the shell. In the other Moringa species, the kernel to shell ratio was significantly lower and in $M$. drouhardii and M. hildebrandtii the shell mass was very similar to the kernel mass (Table 1).

Table 1. Morphometric characteristics of seeds and kernels of four Moringa species

\begin{tabular}{|c|c|c|c|c|c|}
\hline \multirow[b]{2}{*}{ Species (origin) } & \multicolumn{5}{|c|}{ Characteristics } \\
\hline & $\begin{array}{l}\text { Appearance } \\
\text { (left whole seed, right kernel) }\end{array}$ & $\begin{array}{l}\text { Single seed } \\
\text { mass (SSM) } \\
(\mathrm{g})\end{array}$ & $\begin{array}{l}\text { Seed hull } \\
\text { mass (SHM) } \\
(\mathrm{g})\end{array}$ & $\begin{array}{l}\text { Single kernel } \\
\text { mass }(\mathrm{SKM}) \\
(\mathrm{g})\end{array}$ & $\begin{array}{l}\text { Ratio kernel/shell } \\
(\mathrm{KSR})\end{array}$ \\
\hline $\begin{array}{l}\text { M. oleifera } \\
\text { (Managua, Nicaragua) }\end{array}$ & & $0.32 \pm 0.06^{\mathrm{a}}$ & $0.08 \pm 0.02^{\mathrm{a}}$ & $0.24 \pm 0.05^{\mathrm{a}}$ & $3.16 \pm 0.50^{\mathrm{c}}$ \\
\hline $\begin{array}{l}\text { M. stenopetala } \\
\text { (Negev, Israel) }\end{array}$ & & $1.09 \pm 0.11^{\mathrm{b}}$ & $0.38 \pm 0.05^{b}$ & $0.70 \pm 0.07^{\mathrm{b}}$ & $1.85 \pm 0.21^{\mathrm{b}}$ \\
\hline $\begin{array}{l}\text { M. drouhardii } \\
\text { (Toliara, Madagascar) }\end{array}$ & & $3.14 \pm 0.71^{\mathrm{c}}$ & $1.47 \pm 0.31^{\mathrm{c}}$ & $1.67 \pm 0.55^{\mathrm{c}}$ & $1.16 \pm 0.41^{\mathrm{a}}$ \\
\hline $\begin{array}{l}\text { M. hildebrandtii } \\
\text { (Gran Canary) }\end{array}$ & & $3.87 \pm 0.72^{\mathrm{c}}$ & $1.78 \pm 0.39^{c}$ & $2.08 \pm 0.49^{c}$ & $1.20 \pm 0.26^{\mathrm{a}}$ \\
\hline
\end{tabular}

Note. $\mathrm{N}=10$, mean \pm standard deviation. Values in the same coloumn with different superscripts are statistically different $(\mathrm{P} \leq 0.05)$. 


\subsection{Proximate Compositions}

The crude protein content ranged from $188 \mathrm{~g} / \mathrm{kg}$ (M. stenopetala) to $375 \mathrm{~g} / \mathrm{kg}$ (M. oleifera) of the kernels and from $197 \mathrm{~g} / \mathrm{kg}$ (M. drouhardii) to $277 \mathrm{~g} / \mathrm{kg}$ (M. oleifera) of the leaves. The crude lipid content ranged from 227 $\mathrm{g} / \mathrm{kg}$ (M. drouhardii) to $482 \mathrm{~g} / \mathrm{kg}$ (M. hildebrandtii) of the kernels and from $37 \mathrm{~g} / \mathrm{kg}$ (M. drouhardii) to $52 \mathrm{~g} / \mathrm{kg}$ (M. hildebrandtii) of the leaves (Table 2).

Table 2. Overview of the origins of the different Moringa spp. leaf and kernel samples and their proximate compositions ( $\mathrm{g} / \mathrm{kg} \mathrm{DM})$

\begin{tabular}{llllll}
\hline Plant part & Species & Origin & Water & Crude protein (CP) & Crude lipids (CL) \\
\hline Leaves & M. oleifera & Malawi & & 277 & \\
Leaves & M. drouhardii & Madagascar & & 197 & 37 \\
Leaves & M. hildebrandtii & Gran Canary & & 222 & 52 \\
Kernel & M. oleifera & Nicaragua & 49 & 367 & 374 \\
Kernel & M. oleifera & India & 48 & 375 & 370 \\
Kernel & M. oleifera & Ethiopia & 61 & 347 & 285 \\
Kernel & M. stenopetala & Israel & 53 & 188 & 315 \\
Kernel & M. drouhardii & Madagascar & & & 227 \\
Kernel & M. hildebrandtii & Gran Canary & 41 & 275 & 482 \\
\hline
\end{tabular}

\subsection{Amino Acid Composition of Leaves and Kernels}

The amino acid composition (\% of CP) is given in Table 3. There were no striking differences in the composition of the tested Moringa varieties. Compared to the AA contents of the leaves, kernel meal is generally relatively poorer in EAA, except for sulphur-containing AA (Methionine and Cysteine). The major non-essential amino acids in kernels and leaves were glutamic and aspartic acid, arginine, proline and glycine (Table 3).

Table 3. Amino acid (AA) profiles of the various Moringa spp. leaf and kernel samples (data given as \% of CP)

\begin{tabular}{|c|c|c|c|c|c|c|c|c|c|}
\hline \multirow{3}{*}{$\begin{array}{l}\text { Species } \\
\text { Plant part } \\
\text { Origin }\end{array}$} & & \multirow{3}{*}{$\begin{array}{l}\text { M. oleifera } \\
\text { Leaves } \\
\text { Malawi }\end{array}$} & \multirow{3}{*}{$\begin{array}{l}\text { M. drouhardii } \\
\text { Leaves } \\
\text { Madagascar }\end{array}$} & \multirow{3}{*}{$\begin{array}{l}\text { M. hildebrandtii } \\
\text { Leaves } \\
\text { Gran Canary }\end{array}$} & \multirow{3}{*}{$\begin{array}{l}\text { M. oleifera } \\
\text { Kernel } \\
\text { Nicaragua }\end{array}$} & \multirow{3}{*}{$\begin{array}{l}\text { Kernel } \\
\text { India }\end{array}$} & \multirow{3}{*}{$\begin{array}{l}\text { Kernel } \\
\text { Ethiopia }\end{array}$} & \multirow{3}{*}{$\begin{array}{l}\text { M. stenopetala } \\
\text { Kernel } \\
\text { Israel }\end{array}$} & \multirow{3}{*}{$\begin{array}{l}\text { M. hildebrandtii } \\
\text { Kernel } \\
\text { Gran Canary }\end{array}$} \\
\hline & & & & & & & & & \\
\hline & & & & & & & & & \\
\hline \multicolumn{10}{|l|}{ Essential $A A$} \\
\hline Methionine & Met & 1.66 & 1.67 & 1.31 & 1.93 & 1.92 & 1.82 & 1.70 & 1.93 \\
\hline Valine & Val & 4.69 & 5.00 & 4.01 & 3.49 & 3.31 & 3.43 & 3.78 & 3.16 \\
\hline Isoleucine & Ile & 4.01 & 4.22 & 3.24 & 2.97 & 3.01 & 2.74 & 3.09 & 2.98 \\
\hline Leucine & Leu & 7.65 & 7.71 & 6.08 & 5.42 & 5.39 & 5.53 & 5.48 & 5.56 \\
\hline Phenylalanine & Phe & 6.28 & 5.16 & 4.37 & 4.14 & 4.05 & 3.86 & 4.15 & 4.40 \\
\hline Histidine & His & 2.35 & 2.34 & 2.25 & 2.40 & 2.35 & 2.51 & 2.61 & 2.40 \\
\hline Lysine & Lys & 5.20 & 5.26 & 4.46 & 1.66 & 1.55 & 2.39 & 1.86 & 1.82 \\
\hline Threonine & Thr & 4.26 & 4.32 & 4.05 & 2.48 & 2.37 & 2.82 & 2.77 & 2.65 \\
\hline Tryptophan & Trp & 2.06 & 1.93 & 1.80 & 0.90 & 0.93 & 0.95 & 0.96 & 0.87 \\
\hline \multicolumn{10}{|c|}{ Non-essential AA } \\
\hline Cystine & Cys & 1.34 & 1.56 & 1.67 & 4.09 & 4.13 & 3.69 & 3.51 & 3.85 \\
\hline Aspartic acid & Asp & 9.46 & 9.95 & 13.6 & 4.44 & 4.32 & 5.50 & 5.05 & 4.29 \\
\hline Proline & Pro & 4.91 & 4.69 & 4.01 & 5.89 & 6.08 & 6.46 & 5.27 & 5.82 \\
\hline Serine & Ser & 4.48 & 4.27 & 5.23 & 2.97 & 2.91 & 2.80 & 3.03 & 3.05 \\
\hline Tyrosine & Tyr & 3.14 & 3.07 & 2.57 & 1.72 & 1.63 & 1.64 & 1.54 & 1.49 \\
\hline Glutamic acid & Glu & 13.8 & 10.8 & 11.7 & 21.1 & 20.9 & 19.9 & 20.4 & 19.2 \\
\hline Glycine & Gly & 4.69 & 4.84 & 4.50 & 5.20 & 4.85 & 4.55 & 5.21 & 4.65 \\
\hline Alanine & Ala & 5.67 & 5.42 & 4.41 & 3.84 & 3.76 & 3.37 & 3.88 & 3.35 \\
\hline Arginine & Arg & 5.52 & 5.36 & 4.55 & 15.0 & 14.9 & 13.3 & 12.1 & 14.3 \\
\hline
\end{tabular}




\subsection{Fatty Acids}

The fatty acid profiles, which were only analysed in lipids extracted from the kernels, were relatively low in variation. In all species, the single most important FA was the monounsaturated oleic acid (C18:1n-9), which made up between 66 and almost $75 \%$ of the total crude lipids, followed by the saturated palmitic (C16:0) and stearic acids (C18:0). Behenic acid (22:0) is characteristic for Moringa oil and ranged from $2.3 \%$ in $M$. drouhardii to $5.58 \%$ in seeds of $M$. oleifera from India. The total unsaturated fatty acids (UFA) were slightly lower in M. oleifera and M. hildebrandtii than in M. stenopetala and M. drouhardii (around 73\% and 76\% of CL, respectively) (Table 4). Only two poly-unsaturated fatty acids (PUFA) were determined in the analyses: the cis variants of linoleic acid (C18:2 n-6c) and linolenic acid (C18:3 n-3c). Both PUFAs were found to be less concentrated in kernels of $M$. drouhardii than in all other samples.

Table 4. Fatty acid profiles of the various Moringa spp. kernel samples (data given as \% of CL)

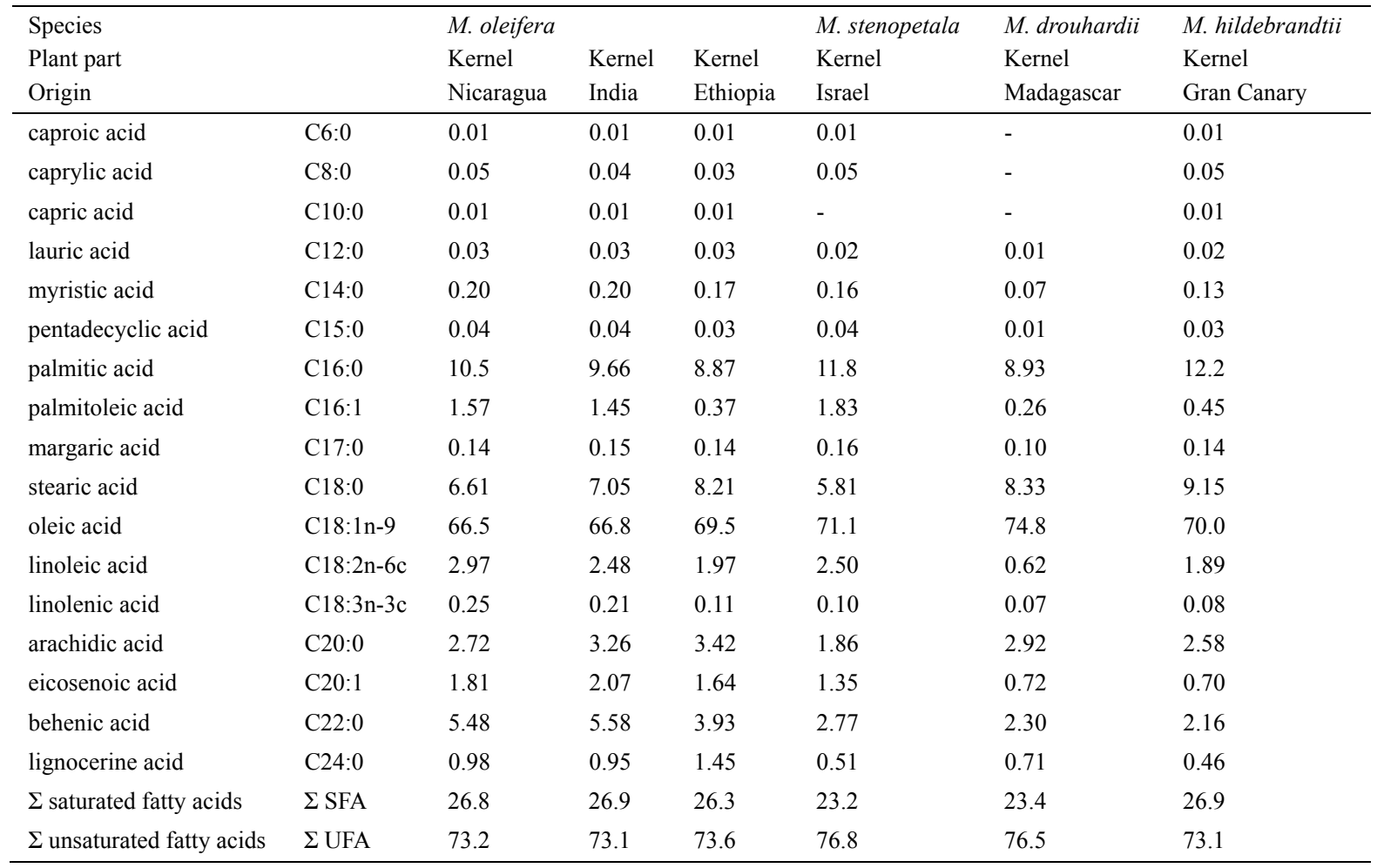

\subsection{Elemental Analysis}

Calcium (> $20 \mathrm{~g} / \mathrm{kg} \mathrm{DM}$ ), phosphorous and potassium were the major macroelements in leaves although $M$. oleifera leaves from India were rather low in calcium $(11 \mathrm{~g} / \mathrm{kg} \mathrm{DM})$. Potassium and phosphorous were the dominant macroelements in the kernels but kernels seemed to have generally lower levels of macroelements than the leaves (Table 5). Iron and silicon were the main microelements in both kernels and leaves in terms of quantity (Table 6). Of the harmful elements, aluminium was dominant with contents as high as $614 \mu \mathrm{g} / \mathrm{kg} \mathrm{DM}$ (M. oleifera leaves from Uganda) and $862 \mu \mathrm{g} / \mathrm{kg}$ DM (M. oleifera leaves from Malawi) (Table 7). 
Table 5. Macroelements of the various Moringa spp. leaf and kernel samples ( $\mathrm{g} / \mathrm{kg} \mathrm{DM})$

\begin{tabular}{llllllll}
\hline Plant part & Species & Origin & $\mathrm{Ca}$ & $\mathrm{P}$ & $\mathrm{Mg}$ & $\mathrm{K}$ & $\mathrm{Na}$ \\
\hline Leaves & M. oleifera & Nicaragua & 20.8 & 3.36 & 3.69 & 18.8 & 0.70 \\
Leaves & M. oleifera & India & 11.0 & 6.32 & 3.73 & 29.6 & 0.67 \\
Leaves & M. oleifera & Malawi & 22.2 & 3.70 & 8.79 & 13.5 & 0.60 \\
Leaves & M. oleifera & Thailand & 23.7 & 3.07 & 3.68 & 19.3 & 0.45 \\
Leaves & M. oleifera & Uganda & 21.6 & 2.59 & 4.20 & 17.3 & 0.29 \\
Leaves & M. drouhardii & Madagascar & 11.9 & 2.19 & 9.06 & 12.3 & 9.78 \\
Leaves & M. hildebrandtii & Gran Canary & 15.7 & 4.66 & 4.90 & 19.5 & 5.04 \\
Kernel & M. oleifera & Ethiopia & 2.53 & 8.28 & 4.15 & 11.3 & 0.04 \\
Kernel & $M$. stenopetala & Israel & 1.45 & 3.62 & 2.37 & 5.64 & 0.49 \\
Kernel & M. drouhardii & Madagascar & 0.75 & 3.55 & 1.83 & 7.84 & 0.15 \\
Kernel & $M$. hildebrandtii & Gran Canary & 0.87 & 8.03 & 2.79 & 9.03 & 0.06 \\
\hline
\end{tabular}

Table 6. Microelements of the various Moringa spp. leaf and kernel samples (mg/kg DM)

\begin{tabular}{lllllllllllllll}
\hline Plant part & Species & Origin & $\mathrm{Fe}$ & $\mathrm{Zn}$ & $\mathrm{Mn}$ & $\mathrm{Mo}$ & $\mathrm{Co}$ & $\mathrm{Se}$ & $\mathrm{Si}$ & $\mathrm{Cu}$ & $\mathrm{B}$ & $\mathrm{As}$ & $\mathrm{V}$ \\
\hline Leaves & M. oleifera & Nicaragua & 229 & 20.7 & 71.4 & 1.30 & 0.083 & 2.85 & 343 & 5.37 & 32.2 & $<0.734$ & 0.276 \\
Leaves & M. oleifera & India & 132 & 30.1 & 16.7 & 0.518 & 0.080 & 1.57 & 248 & 5.89 & 29.1 & $<0.721$ & 0.136 \\
Leaves & M. oleifera & Malawi & 1239 & 21.7 & 76.9 & 4.53 & 0.860 & 27.7 & 279 & 8.21 & 64.6 & $<0.725$ & 3.64 \\
Leaves & M. oleifera & Thailand & 132 & 21.0 & 79.4 & 1.13 & 0.081 & 0.978 & 260 & 6.59 & 52.4 & $<0.726$ & 0.204 \\
Leaves & M. oleifera & Uganda & 581 & 17.7 & 116 & 1.27 & 0.437 & 2.27 & 286 & 5.79 & 57.4 & $<0.717$ & 1.21 \\
Leaves & M. drouhardii & Madagascar & 138 & 12.2 & 79 & 1.46 & $<0.082$ & $<0.653$ & 389 & 4.23 & 126 & $<0.816$ & 0.215 \\
Leaves & M. hildebrandtii & Gran Canary & 350 & 21.8 & 80.5 & 1.6 & 0.248 & $<0.645$ & 192 & 2.52 & 62.7 & $<0.806$ & 0.733 \\
Kernel & M. oleifera & Ethiopia & 123 & 34.2 & 17.7 & $<0.241$ & 0.081 & $<0.644$ & 124 & 4.91 & 7.93 & $<0.804$ & 0.189 \\
Kernel & M. stenopetala & Israel & 21.2 & 21.7 & 9.16 & $<0.238$ & $<0.08$ & $<0.636$ & 9.73 & 3.01 & 6.14 & $<0.795$ & $<0.08$ \\
Kernel & M. drouhardii & Madagascar & 39.7 & 14.7 & 5.34 & 0.283 & $<0.081$ & $<0.645$ & 33.5 & 3.56 & 7.35 & $<0.806$ & $<0.081$ \\
Kernel & M. hildebrandtii & Gran Canary & 24.1 & 27 & 5.11 & $<0.243$ & $<0.081$ & 0.796 & 5.38 & 3.91 & 6.31 & $<0.809$ & $<0.081$ \\
\hline
\end{tabular}

Table 7. Potentially essential and toxic heavy metals and minerals of the various Moringa spp. leaf and kernel samples $(\mathrm{mg} / \mathrm{kg} \mathrm{DM})$

\begin{tabular}{|c|c|c|c|c|c|c|c|c|c|c|c|c|c|c|}
\hline Plant part & Species & Origin & $\mathrm{Pb}$ & $\mathrm{Cd}$ & $\mathrm{Ag}$ & $\mathrm{Al}$ & $\mathrm{Ba}$ & $\mathrm{Ni}$ & $\mathrm{Cr}$ & $\mathrm{Sn}$ & $\mathrm{Li}$ & $\mathrm{Ge}$ & $\mathrm{Sb}$ & $\mathrm{Sr}$ \\
\hline Leaves & M. oleifera & Nicaragua & .408 & $<0.082$ & $<0.163$ & 79.7 & 37.4 & 0.681 & 0.557 & $<0.652$ & 0.653 & $<0.489$ & $<0.571$ & 66.9 \\
\hline Leaves & M. oleifera & India & $<0.400$ & $<0.080$ & $<0.160$ & 65.3 & 11.9 & 1.49 & 0.488 & $<0.641$ & 0.165 & $<0.480$ & $<0.560$ & 21.2 \\
\hline Leaves & M. oleifera & Malawi & 0.59 & $<0.080$ & $<0.161$ & 862 & 37.4 & 3.80 & 5.15 & $<0.644$ & 0.987 & $<0.483$ & $<0.564$ & 126 \\
\hline Leaves & M. oleifera & Thailand & $<0.403$ & $<0.081$ & $<0.161$ & 88.2 & 9.44 & 0.646 & 0.283 & $<0.645$ & 2.63 & $<0.484$ & $<0.565$ & 34.5 \\
\hline Leaves & M. oleifera & Uganda & $<0.398$ & $<0.080$ & $<0.159$ & 614 & 73.2 & 1.56 & 1.03 & $<0.637$ & 0.459 & $<0.478$ & $<0.557$ & 149 \\
\hline Leaves & M. drouhardii & Madagascar & $<0.408$ & $<0.057$ & $<0.245$ & 80.6 & 3.18 & 0.729 & 0.466 & 0.676 & 1.64 & $<0.49$ & $<0.572$ & 28.4 \\
\hline Leaves & M. hildebrandtii & Gran Canary & $<0.403$ & $<0.056$ & $<0.272$ & 301 & 7.07 & 1.86 & 0.7 & 0.605 & 0.907 & $<0.484$ & $<0.564$ & 58.6 \\
\hline Kernel & M. oleifera & Ethiopia & $<0.402$ & $<0.056$ & $<0.241$ & 65.7 & 2.48 & 0.886 & 0.469 & 0.466 & $<0.161$ & $<0.483$ & $<0.563$ & 16.8 \\
\hline Kernel & M. stenopetala & Israel & $<0.397$ & 0.068 & $<0.238$ & 2.81 & $<0.08$ & 1.66 & 0.604 & $<0.397$ & $<0.159$ & $<0.477$ & $<0.556$ & 24.4 \\
\hline Kernel & M. drouhardii & Madagascar & $<0.403$ & $<0.056$ & $<0.242$ & 15.4 & 0.226 & 1.56 & 2.08 & $<0.403$ & $<0.161$ & $<0.484$ & $<0.564$ & 37.1 \\
\hline Kernel & M. hildebrandtii & Gran Canary & $<0.404$ & $<0.057$ & $<0.243$ & 1.3 & 0.319 & 0.741 & 0.131 & 0.428 & $<0.162$ & $<0.485$ & $<0.566$ & 33.3 \\
\hline
\end{tabular}

\subsection{Vitamins}

Vitamin C (29.2 $\mathrm{mg} / 100 \mathrm{~g})$ and niacin $(11 \mathrm{mg} / 100 \mathrm{~g})$ were the major water soluble vitamins followed by vitamin B2 $(2.30 \mathrm{mg} / 100 \mathrm{~g})$ and pantothenic acid $(2.15 \mathrm{mg} / 100 \mathrm{~g})$. Of the water insoluble vitamins, vitamin $\mathrm{E}$ (DL-tocopherol, $44.5 \mathrm{mg} / 100 \mathrm{~g}$ ) was the major vitamin followed by $\beta$-carotene $(8030 \mu \mathrm{g} / 100 \mathrm{~g}$ ) (Table 8). 
Table 8. Vitamins measured in the leaves of M. oleifera from Malawi

\begin{tabular}{llll}
\hline & Unit (on dry matter basis) & Method of analysis & M. oleifera leaf meal \\
\hline Water soluble vitamins & & & \\
Biotin & $\mu \mathrm{g} / 100 \mathrm{~g}$ & AOAC certificate 101001 & 29.5 \\
Folic acid & $\mathrm{mg} / 100 \mathrm{~g}$ & AOAC certificate 100903 & 0.78 \\
Niacin & $\mathrm{mg} / 100 \mathrm{~g}$ & VitaFast ${ }^{\circledR}$ ifp & 11 \\
Vitamin B1 & $\mathrm{mg} / 100 \mathrm{~g}$ & VitaFast ${ }^{\circledR}$ ifp & 0.27 \\
Pantothenic acid & $\mathrm{mg} / 100 \mathrm{~g}$ & AOAC certificate 100904 & 2.15 \\
Vitamin B2 & $\mathrm{mg} / 100 \mathrm{~g}$ & AOAC certificate 100902 & 2.30 \\
Vitamin B6 & $\mathrm{mg} / 100 \mathrm{~g}$ & VitaFast ${ }^{\circledR}$ ifp & 1.15 \\
Vitamin C & $\mathrm{mg} / 100 \mathrm{~g}$ & DIN EN 14130 & 29.2 \\
Water insoluble vitamins & & & \\
$\beta$-carotene (Vitamin-A precursor) & $\mathrm{mg} / 100 \mathrm{~g}$ & DIN EN 12823-2 & 8.03 \\
Vitamin K1 & $\mathrm{mg} / 100 \mathrm{~g}$ & DIN EN 14148 & 0.898 \\
Vitamin E (DL-Tocopherol) & $\mathrm{mg} / 100 \mathrm{~g}$ & DIN EN 12822 & 44.5 \\
\hline
\end{tabular}

\section{Discussion}

Of the 13 described Moringa species, one has been given the vast majority of scientific and public attention. The search term "Moringa oleifera", when entered in the Web of Knowledge search (www.webofknowledge.com), yielded 1465 results, while the search term "Moringa stenopetala" yielded 61; "Moringa drouhardii" yielded 4; and "Moringa hildebrandtii" yielded 2 results (search conducted on the 14 $14^{\text {th }}$ of March 2017). The large discrepancy in scientific interest is likely based on several important and advantageous properties of M. oleifera; of which the most important and well known is probably the coagulation ability of specific seed proteins (Olsen, 1987; Gassenschmidt et al., 1995; Muyibi \& Evison, 1995; Ndabigengesere, Narasiah, \& Talbot, 1995; Ndabigengesere \& Narasiah, 1998). Other reasons that M. oleifera has been the focus of study are the potential utilization of the seeds as a feed additive (Ben Salem \& Makkar, 2009; Hlophe \& Moyo, 2014; T. P. Singh, P. Singh, \& Kumar, 2015) or insecticide (Benelli, 2015); the importance of the leaves for human nutrition (Subadra, Monica, \& Dhabhai, 1997; Babu, 2000; Fahey, 2005; Thurber \& Fahey, 2009); including its potential use as a human famine food (Sena et al., 1998) and as animal feed (Richter et al., 2003; Negesse, Makkar, \& Becker, 2009; Abbas, 2013) and the medical potential of all plant parts (Anwar et al., 2007; Jaeschke, Williams, McGill, Xie, \& Ramachandran, 2013); including the antibiotic activity of pods, flowers and leaves (Brilhante et al., 2015).

Generally, it is more common to utilize Moringa leaves as food and feed than Moringa kernels. The necessary amount of dry matter intake to cover $15 \%$ of the respective nutrient demand of a child (Golden, 2009) is calculated for leaves of M. oleifera, M. hildebrandtii and M. drouhardii and presented in Table 9. As a source for protein and essential amino acids (EAA), M. oleifera leaves are superior to the leaves of $M$. hildebrandtii and $M$. drouhardii. This is especially the case for isoleucine, phenylalanine + tyrosine, lysine and tryptophan (Tables 3 and 9). A potentially high food value of $M$. oleifera leaf protein as an EAA source can be justified in that the analysed amino acid patterns almost completely satisfied the requirement of a 2-5 year old child. All analysed Moringa leaves contained all essential amino acids except lysine in higher concentrations than recommended for the young child (Zarkadas, Yu, \& Burrows, 1995). Moringa spp. kernels, however, were rather poor in EAA when compared to leaves (Table 3). All Moringa kernels were deficient in leucine, phenylalanine, lysine, threonine and tryptophan. 
Table 9. Necessary amount of leaf dry matter intake $(\mathrm{g})$ to cover $15 \%$ of the daily requirement of a child for the given nutrient of Moringa leaves. Requirement values from Golden (2009), with data from FAO where available, otherwise data from other sources (e.g. Institute of Medicine, IOM)

\begin{tabular}{|c|c|c|c|c|c|}
\hline \multirow[b]{2}{*}{ Nutrient } & \multirow[b]{2}{*}{ Unit } & \multirow[b]{2}{*}{ Childs requirement } & \multicolumn{3}{|c|}{ Species } \\
\hline & & & $\begin{array}{l}\text { M. oleifera } \\
\text { Various }{ }^{1}\end{array}$ & $\begin{array}{l}\text { M. hildebrandtii } \\
\text { Gran Canary }\end{array}$ & $\begin{array}{l}\text { M. drouhardii } \\
\text { Madagascar }\end{array}$ \\
\hline Protein & $\mathrm{g}$ & 22.3 & 12.1 & 15.1 & 17.4 \\
\hline Methionine + Cysteine & $\mathrm{mg}$ & 575 & 10.4 & 13.1 & 13.9 \\
\hline Valine & $\mathrm{mg}$ & 776 & 8.95 & 13.1 & 12.1 \\
\hline Isoleucine & $\mathrm{mg}$ & 575 & 7.77 & 12.0 & 10.6 \\
\hline Leucine & $\mathrm{mg}$ & 1245 & 8.81 & 13.8 & 12.6 \\
\hline Phenylalanine + Tyrosine & $\mathrm{mg}$ & 1125 & 6.47 & 11.0 & 10.7 \\
\hline Histidine & $\mathrm{mg}$ & 430 & 9.92 & 12.9 & 14.3 \\
\hline Lysine & $\mathrm{mg}$ & 1190 & 12.4 & 18.0 & 17.7 \\
\hline Threonine & $\mathrm{mg}$ & 655 & 8.33 & 10.9 & 11.8 \\
\hline Tryptophan & $\mathrm{mg}$ & 175 & 4.61 & 6.56 & 7.09 \\
\hline Calcium & $\mathrm{mg}$ & 595 & 5.13 & 5.70 & 7.47 \\
\hline Phosphorous & $\mathrm{mg}$ & 450 & 18.8 & 14.5 & 30.9 \\
\hline Magnesium & $\mathrm{mg}$ & 79 & 2.64 & 2.42 & 1.31 \\
\hline Potassium & $\mathrm{mg}$ & 1099 & 9.01 & 8.47 & 13.4 \\
\hline Sodium & $\mathrm{mg}$ & 978 & 293 & 29.1 & 15.0 \\
\hline Iron & $\mathrm{mg}$ & 17.8 & 9.66 & 7.63 & 126 \\
\hline Zinc & $\mathrm{mg}$ & 12.5 & 86.3 & 86.0 & 86.4 \\
\hline Manganese & $\mathrm{mg}$ & 1.2 & 4.30 & 2.24 & 19.7 \\
\hline Molybdenum & $\mu \mathrm{g}$ & 16.6 & 2.31 & 1.56 & - \\
\hline Selenium & $\mu \mathrm{g}$ & 17.8 & 0.98 & - & - \\
\hline Copper & $\mu \mathrm{g}$ & 892 & 21.8 & 53.1 & 44.5 \\
\hline Chromium & $\mu \mathrm{g}$ & 10.8 & 2.03 & 2.31 & 2.68 \\
\hline
\end{tabular}

Note. ${ }^{1}$ Protein and amino acid data where only available for M. oleifera leaves from Malawi, values for dry matter intake for macro- and microelements are the mean of M. oleifera leaves from Nicaragua, India, Malawi, Thailand and Uganda.

All Moringa spp. leaves were excellent sources for the macro-elements calcium and magnesium. As little as 5.0-7.5 and 1.3-2.4 $\mathrm{g}$ of dry leaf powder satisfy $15 \%$ of a child's daily calcium and magnesium requirement (Tables 5 and 9), respectively. The phosphorous content was lower than the calcium and magnesium content in M. oleifera and M. hildebrandtii, while phosphorous content was found to be even lower in M. drouhardii. For a growing child, calcium and phosphorous are especially important as both are necessary for bone mineralization and thus for sustained growth (FAO, 2001). As a source of iron, only leaves of M. oleifera and M. hildebrandtii were sufficient. The iron content of $M$. drouhardii leaves was very low and the required leave meal quantity to cover $15 \%$ of a child's daily need was extremely high (Table 9). In comparison to other green leafy vegetables (e.g. spinach, cauliflower, amaranth), the analysed iron contents in Moringa spp. leaves were higher while those of Moringa spp. kernels were lower or similar (Singh, Kawatra, \& Sehgal, 2001). High amounts of aluminium were measured in M. hildebrandtii leaf samples and in M. oleifera leaf samples from Malawi and Uganda, which might point to either high aluminium contents in the soils or abrasion in the mills. Wastewater irrigation is usually also a possible source of minerals and heavy metals (Arora et al., 2008) but the plantations from which the samples were collected do not use this type of combined irrigation and fertilization, so this potential source can be excluded. The iron and aluminium content in canola (Brassica napus L.) has also been found to vary with the plant's growth stage; showing a negative correlation between mineral content and plant age (Miller-Cebert, Sistani, \& Cebert, 2009). Of the other microelements, M. oleifera and M. hildebrandtii leaves contained concentrations of manganese, chromium and molybdenum that a DM intake of only between 1.56 (molybdenum, M. hildebrandtii) and $4.30 \mathrm{~g}$ (manganese, M. oleifera) per day are sufficient to cover $15 \%$ of the daily requirement. Zinc and copper were found in relatively low concentrations, so Moringa leaves are not well suited to deliver the recommended daily doses. The selenium concentrations were on average very high in M. oleifera 
leaves, but the leaves from M. oleifera harvested in Malawi showed exceptionally high selenium values (Table 6) while the other samples where considerably lower.

Moringa leaves were found to be not particularly dense in energy as their lipid content was low $(37 \mathrm{~g} / \mathrm{kg}$ DM in $M$. hildebrandtii and $52 \mathrm{~g} / \mathrm{kg}$ DM in $M$ drouhardii leaves). The kernels, however, had high lipid contents well above $300 \mathrm{~g} / \mathrm{kg} \mathrm{DM}$ in M. oleifera (Table 2). Kernels of M. hildebrandtii were exceptionally rich in lipids while those of M. drouhardii were comparatively poor (482 and $227 \mathrm{~g} / \mathrm{kg} \mathrm{DM}$, respectively). Kernel lipids of all the analysed Moringa spp. were rich in oleic-acid which is also the most important mono-unsaturated fatty acid in Western diets but nutritionally less valuable than poly-unsaturated fatty acids (FAO, 2010). The Ben oil extracted from M. oleifera kernels is known for a long shelf life and has been used for salads and industrial applications with higher emphasis on the industrial uses (Tsaknis, Lalas, Gergis, Dourtoglou, \& Spiliotis, 1999). As a lipid source the kernels of $M$. hildebrandtii would be better suited although their low kernel to shell ratio is less favourable than in M. oleifera.

Vitamin $\mathrm{A}$ is a fat soluble vitamin that plays an important role in metabolism: primarily for the visual functioning; growth and development; epithelial cellular integrity; immune functioning; and reproduction (FAO, 2001). It is mainly stored in animals and humans in the fat storing cells in the liver as esterified retinyl but carotenoids are also stored in other fat tissues in the body. One important precursor for vitamin A or retinol, is the long chain, lipophilic carotenoid $\beta$-carotene. The FAO lists $1 \mu \mathrm{g} \beta$-carotene as being equivalent to $0.167 \mu \mathrm{g}$ retinol or retinol-equivalents (RE). It is thus the most important and readily available precursor for the important fat-soluble vitamin (FAO, 2001) since the conversion for other carotenoids is $1 \mu \mathrm{g}$ to $0.084 \mathrm{RE}$. The amount of $\beta$-carotene in the leaves of $M$. oleifera from Malawi was $8.03 \mathrm{mg} / 100 \mathrm{~g} \mathrm{DM}$ in our study, which was considerably lower than that reported for M. oleifera leaves from India (17.4 mg/100 g DM) (Subadra et al. 1997) or M. oleifera leaves of unspecified origin ( $16.3 \mathrm{mg} / 100 \mathrm{~g} \mathrm{DM}$ ) (Singh et al., 2001). An adult female between 19 and 65 years of age has a mean vitamin A requirement of $270 \mu \mathrm{g}$ RE/day (FAO, 2001) corresponding to $1617 \mu \mathrm{g}$ $\beta$-carotene/day or $20.1 \mathrm{~g}$ DM of $M$. oleifera leaves from Malawi.

In addition to the macro- and micronutrients that were the focus of this study, Moringa leaves and kernels can contain a variety of different bioactive compounds. Phenols, tannins, saponins, phytate (Makkar \& Becker, 1996; 1997) of varying concentrations have been described in leaves.

Moringa kernels can contain concentrations of glucosinolates (4-( $\alpha$-L-rhamnopyranosyloxy)-benzylglucosinolate) as high as $264 \mathrm{mg} / \mathrm{g}$ DM in M. oleifera and $256 \mathrm{mg} / \mathrm{g}$ DM in M. stenopetala (Bennett et al., 2003). Moringa leaves are seemingly lower in glucosinolate content with concentrations between 5.3 and $70.2 \mathrm{mg} / \mathrm{g} \mathrm{DM}$ (Bennett et al., 2003). They might be the reason for a described antibacterial and antifungal activity (Fahey, Zalcman, \& Talalay, 2001), are believed to play a role in the plant's defence (Redovniković, Glivetić, Delonga, \& Vorkapić-Furač, 2009) and have potential uses for medicinal purposes for humans and animals (Bennett et al., 2003; Brilhante et al., 2015).

\section{Conclusion}

The nutritional patterns of macro- and micronutrients of Moringa spp. leaves and kernels highlight them as potential food and feed source in the tropic and sub-tropic regions where they can be grown effectively. In general, the leaves tend to be the more promising plant parts as vegetables for human consumption, especially so for macroelements. Given the different production systems for seeds and kernels on the one hand (older trees, lower leaf to stem ratio) and leaves on the other hand (very young trees, high leaf to stem ratio, short rotation coppice), either old trees for seed and kernel production or young trees for leaf production can be utilized. In terms of nutrient production it seems to be more promising to produce leaves over kernels and leaves of $M$. oleifera, $M$. hildebrandtii and $M$. drouhardii can be considered nutritionally valuable leafy vegetables.

However, for the product to be ready for human consumption, and also suitable as high quality animal feed ingredient, the production must be safe and free of contaminants and pesticide residues. If that goal is accomplished, especially the nutrient content of the leaves but also the kernel of Moringa spp., allows them to be considered as a meaningful alternative to combatting malnutrition by being consumed directly by humans or indirectly by utilization as animal feed. Controlled clinical trials are, however, necessary to determine the extent to which Moringa can be adopted to combat malnutrition and to evaluate anecdotal knowledge about its beneficial nutritional and medical properties. Our study on macro- and micronutrients helps to close the knowledge gap, although more work is necessary; especially to determine intraspecific variation between different sampling locations versus interspecific variation. 


\section{References}

Abbas, T. E. (2013). The use of Moringa oleifera in poultry diets. Turkish Journal of Veterinary and Animal Sciences, 37, 492-496. https://doi.org/10.3906/vet-1211-40

Afuang, W., Siddhuraju, P., \& Becker, K. (2003). Comparative nutritional evaluation of raw, methanol extracted residues and methanol extracts of Moringa (Moringa oleifera Lam.) leaves on growth performance and feed utilization in Nile tilapia (Oreochromis niloticus L.). Aquaculture Research, 34, 1147-1159. https://doi.org/ 10.1046/j.1365-2109.2003.00920.X

Anwar, F., Latif, S., Ashraf, M., \& Gilani, A. H. (2007). Moringa oleifera: A food plant with multiple medicinal uses. Phytotherapy Research, 21, 17-25. https://doi.org/10.1002/ptr.2023

Arora, M., Kiran, B., Rani, S., Rani, A., Kaur, B., \& Mittal, N. (2008). Heavy metal accumulation in vegetables irrigated with water from different sources. Food Chemistry, 111, 811-815. https://oi.org/10.1016/ j.foodchem.2008.04.049

Babu, S. C. (2000). Rural nutrition interventions with indigenous plant foods - A case study of vitamin A deficiency in Malawi. Biotechnology, Agronomy, Society and Environment, 4, 169-179.

Ben Salem, H., \& Makkar, H. P. S. (2009). Defatted Moringa oleifera seed meal as a feed additive for sheep. Animal Feed Science and Technology, 150, 27-33. https://doi.org/10.1016/j.anifeedsci.2008.07.007

Benelli, G. (2015). Plant-borne ovicides in the fight against mosquito vectors of medical and veterinary importance: A systematic review. Parasitology Research, 114, 3201-3212. https://doi.org/10.1007/ s00436-015-4656-z

Bennett, R. N., Mellon, F. A., Foidl, N., Pratt, J. H., Dupont, M. S., Perkins, L., \& Kroon, P. A. (2003). Profiling glucosinolates and phenolics in vegetative and reproductive tissues of the multi-purpose trees Moringa oleifera L. (horseradish tree) and Moringa stenopetala L. Journal of Agricultural and Food Chemistry, 51, 3546-3553. https://doi.org/10.1021/jf0211480

Brilhante, R. S. N., Sales, J. A., Sampaio, C. M. S., Barbosa, F. G., de Araújo Neto Paiva, M., de Melo Guedes, G. M., ... Rocha, M. F. G. (2015). Vibrio spp. from Macrobrachium amazonicum prawn farming are inhibited by Moringa oleifera extracts. Asian Pacific Journal of Tropical Medicine, 8, 919-922. https://doi.org/10.1016/j.apjtm.2015.10.012

Fahey, J. W. (2005). Moringa oleifera: A review of the medical evidence for its nutritional, therapeutic, and prophylactic properties. Part 1. Trees for Life Journal, 1(5), 1-15. Retrieved November 18, 2015, from http://www.TFLJournal.org/article.php/20051201124931586

Fahey, J. W., Zalcman, A. T., \& Talalay, P. (2001). The chemical diversity and distribution of glucosinolates and isothiocyanates among plants. Phytochemistry, 56, 5-51. https://doi.org/10.1016/S0031-9422(00)00316-2

FAO (UN Food and Agriculture Organization). (2001). Human vitamin and mineral requirements (pp. 1-303). Report of a joint FAO/WHO expert consultation, Bangkok, Thailand. Food and Nutrition Division, FAO, Rome.

FAO (UN Food and Agriculture Organization). (2010). Fats and fatty acids in human nutrition (pp. 1-189). Report of an expert consultation. FAO, Rome.

Gassenschmidt, U., Jany, K. D., Tauscher, B., \& Niebergall, H. (1995). Isolation and characterization of a flocculating protein from Moringa oleifera Lam. Biochimica et Biophysica Acta, 1243, 477-481. https://doi.org/10.1016/0304-4165(94)00176-X

Ghebremichael, K. A., Gunaratna, K. R., Henriksson, H., Brumer, H., \& Dalhammar, G. (2005). A simple purification and activity assay of the coagulant protein from Moringa oleifera seed. Water Research, 39, 2338-2344. https://doi.org/10.1016/j.watres.2005.04.012

Golden, M. H. (2009). Proposed recommended nutrient densities for moderately malnourished children. Food and Nutrition Bulletin, 30, 267-342. https://doi.org/10.1177/15648265090303S302

Hlophe, S. N., \& Moyo, N. A. G. (2014). Replacing fishmeal with kikuyu grass and Moringa leaves: Effects on growth, protein digestibility, histological and haematological parameters in Clarias gariepinus. Turkish Journal of Fisheries and Aquatic Sciences, 14, 795-806. https://doi.org/10.4194/1303-2712-v14_3_22 
Jaeschke, H., Williams, C. D., McGill, M. R., Xie, Y., \& Ramachandran, A. (2013). Models of drug induced liver injury for evaluation of phytotherapeutics and other natural products. Food and Chemical Toxicology, 55, 279-289. https://doi.org/10.1016/j.fct.2012.12.063

Jahn, S. A. A. (1986). Proper use of African natural coagulants for rural water supplies (pp. 65-157). TZ-Verlagsgesellschaft Rossdorf, Rossdorf, Germany.

Leone, A., Spada, A., Battezzati, A., Schiraldi, A., Aristil, J., \& Bertoli, S. (2015). Cultivation, genetic, ethnopharmacology, phytochemistry and pharmacology of Moringa oleifera leaves: An overview. International Journal of Molecular Sciences, 16, 12791-12835. https://doi.org/10.3390/ijms160612791

Makkar, H. P. S., \& Becker, K. (1996). Nutritional value and antinutritional components of whole and ethanol extracted Moringa oleifera leaves. Animal Feed Science and Technology, 63, 211-228. https://doi.org/ 10.1016/S0377-8401(96)01023-1

Makkar, H. P. S., \& Becker, K. (1997). Nutrients and antiquality factors in different morphological parts of the Moringa oleifera tree. Journal of Agricultural Science, 128, 311-322. https://doi.org/10.1017/S00218596 97004292

Miller-Cebert, R. L., Sistani, N. A., \& Cebert, E. (2009). Comparative mineral composition among canola cultivars and other cruciferous leafy greens. Journal of Food Composition and Analysis, 22, 112-116. https://doi.org/10.1016/j.jfca.2008.11.002

Muyibi, S. A., \& Evison, L. M. (1995). Optimizing physical parameters affecting coagulation of turbid water with Moringa oleifera seeds. Water Research, 29, 2689-2695. https://doi.org/10.1016/0043-1354(95) 00133-6

Nambiar, V. S., \& Seshadri, S. (2001). Bioavailability trials of $\beta$-carotene from fresh and dehydrated drumstick leaves (Moringa oleifera) in a rat model. Plant Foods for Human Nutrition, 56, 83-95. https://doi.org/ 10.1023/A:1008132503972

Ndabigengesere, A., \& Narasiah, K. S. (1998). Quality of water treated by coagulation using Moringa oleifera seeds. Water Research, 32, 781-791. https://doi.org/10.1016/S0043-1354(97)00295-9

Ndabigengesere, A., Narasiah, K. S., Talbot, B. G. (1995). Active agents and mechanism of coagulation of turbid waters using Moringa oleifera. Water Research, 29, 703-710. https://doi.org/10.1016/0043-1354(94) 00161-Y

Negesse, T., Makkar, H. P. S., \& Becker, K. (2009). Nutritive value of some non-conventional feed resources of Ethiopia determined by chemical analyses and an in vitro gas method. Animal Feed Science and Technology, 154, 204-217. https://doi.org/10.1016/j.anifeedsci.2009.09.010

Olsen, A. (1987). Low technology water purification by bentonite clay and Moringa oleifera seed flocculation as performed in Sudanese villages: Effects on Schistosoma mansoni cercariae. Water Research, 21, 517-522. https://doi.org/10.1016/0043-1354(87)90059-5

Redovniković, I. R., Glivetić, T., Delonga, K., \& Vorkapić-Furač, J. (2008). Glucosinolates and their potential role in plant. Periodicum Biologorum, 110, 297-309.

Richter, N., Siddhuraju, P., \& Becker, K. (2003). Evaluation of nutritional quality of Moringa (Moringa oleifera Lam.) leaves as an alternative protein source for Nile tilapia (Oreochromis niloticus L.). Aquaculture, 217, 599-611. https://doi.org/10.1016/S0044-8486(02)00497-0

Scheinert, J. (2015). Moringa oleifera: Ernährungsphysiologische Bedeutung und Inhaltsstoffe mit Sonderwirkung. MSc-Thesis University of Hohenheim (in German).

Sena, L. P., Vanderjagt, D. J., Rivera, C., Tsin, A. T. C., Muhamadu, I., Mahamadou, O., ... Glew, R. H. (1998). Analysis of nutritional components of eight famine foods of the Republic of Niger. Plant Foods for Human Nutrition, 52, 17-30. https://doi.org/10.1023/A:1008010009170

Singh, G., Kawatra, A., \& Sehgal, S. (2001). Nutritional composition of selected green leafy vegetables, herbs and carrots. Plant Foods for Human Nutrition, 56, 359-364. https://doi.org/10.1023/A:1011873119620

Singh, T. P., Singh, P., \& Kumar, P. (2015). Drumstick (Moringa oleifera) as a food additive in livestock products. Nutrition and Food Science, 45, 423-432. https://doi.org/10.1108/NFS-02-2015-0018 
Subadra, S., Monica, J., \& Dhabhai, D. (1997). Retention and storage stability of beta-carotene in dehydrated drumstick leaves (Moringa oleifera). International Journal of Food Sciences and Nutrition, 48, 373-379. https://doi.org/10.3109/09637489709028585

Thurber, M. D., \& Fahey, J. W. (2009). Adoption of Moringa oleifera to combat under-nutrition viewed through the lens of the "Diffusion of Innovations" theory. Ecology of Food and Nutrition, 48, 212-225. https://doi.org/10.1080/03670240902794598

Tsaknis, J., Lalas, S., Gergis, V., Dourtoglou, V., \& Spiliotis, V. (1999). Characterization of Moringa oleifera variety Mbololo seed oil of Kenya. Journal of Agricultural and Food Chemistry, 47, 4495-4499. https://doi.org/10.1021/jf9904214

Yuangsoi, B., \& Masumoto, T. (2012). Replacing moringa leaf (Moringa oleifera) partially by protein replacement in soybean meal of fancy carp (Cyprinus carpio). Songklanakarin Journal of Science and Technology, 34, 479-485.

Zarkadas, C. G., Yu, Z., \& Burrows, V. D. (1995). Protein quality of three new Canadian-developed naked oat cultivars using amino acid compositional data. Journal of Agricultural and Food Chemistry, 43, 415-421. https://doi.org/10.1021/jf00050a030

\section{Copyrights}

Copyright for this article is retained by the author(s), with first publication rights granted to the journal.

This is an open-access article distributed under the terms and conditions of the Creative Commons Attribution license (http://creativecommons.org/licenses/by/4.0/). 